\title{
First Community in Abandoned Pasture Lands or Crops in Eastern Cuba's Rainforest over Metamorfics Rocks
}

\author{
Orlando Joel Reyes, Félix Acosta Cantillo, Luz Margarita Figueredo Cardona, \\ Pedro Bergues Garrido
}

Eastern Center of Ecosystems and Biodiversity, Ministry of Science, Tecnology and Environment, Santiago de Cuba, Cuba

\author{
Email address: \\ joel@bioeco.cu (O. J. Reyes)
}

\section{To cite this article:}

Orlando Joel Reyes, Félix Acosta Cantillo, Luz Margarita Figueredo Cardona, Pedro Bergues Garrido. First Community in Abandoned Pasture Lands or Crops in Eastern Cuba's Rainforest over Metamorfics Rocks. Science Journal of Energy Engineering.

Vol. 9, No. 3, 2021, pp. 36-41. doi: 10.11648/j.sjee.20210903.12

Received: July 5, 2021; Accepted: August 10, 2021; Published: October 19, 2021

\begin{abstract}
Miconio prasinae-Cyatheion arboreae alliance is described. Although it has five associations, we address three in this work, corresponding to immediate, secondary and early successional communities in abandoned pasture lands or crops in submountains rainforest over metamorphic rocks. The objective of this work is to study the first communities in used and abandoned fields, because they are of a great importance in the understanding of the vegetation's evolution and for management purposes. In the submontane forest on the metamorphic complex, the destruction of mature vegetation produces important losses in climatic biodiversity and transcendental changes in ecosystem composition. The change in soil use, especially the transformation to pastureland, has favored the development of herbaceous and shrubby plant communities. This study is not only of practical relevance in describing the associations of the pine forests the plant associations and the study of the ecological conditions in which they develop, but its results can be used as a working tool in the environmental management and silviculture for the restoration of degraded areas. The study of diverse Cuban vegetation types suggests that the methodology of Zurich Montpellier's school is more effective as compared to other authors because its syntaxa is good to recognize and is able to transform in a forest typology. The main species are pioneers heliophilous with a type of " $\mathrm{r}$ " selection.
\end{abstract}

Keywords: Ecological Succession, Secoundary Communities, Sierra del Purial, Eastern Cuba

\section{Introduction}

Although there are some works about succession in Cuban forest $[8,15,16]$; there was not enough those made on mountain areas [18].

In submountain rainforest over metamorphic complex [18] destruction of maturity vegetation produce important loses in climacic biodiversity and transcendental changes in ecosystemic composition. In a similar ecosystem Caluff [4] and Sanchez-Ruiz $[22,23]$ had quantify heavy losses of pteridological and spiders diversity with the change of use of soils, getting the maximum with pasturelands transformation.

The objective of this work is to study the evolution of first communities in used and abandoned fields in the submountain rainforest ecotopes over metamorphic complex in rainiest areas of Cuban archipelago.

\section{Methodology}

Natural conditions of the studied area.

The area is inside the more rainy territory of Cuban archipelago, between 2500 to $3000 \mathrm{~mm}$ [13] regularity distributed. Geology is represented by Sierra del Purial Formation [7], composed by different kind of schist, intermediate tuffs between other rocks. Relief is very dissected with slopes between 35 and $45^{\circ}$ rarely less. Soil is ferralitic red and leached red-brown colour [14], frequently little deep, over ferralitic weathering crust.

Sampling methodology

According to Braun Blanquet [3] methodology phytocoenological inventories (lists, stands, samples, relevés), with a minimum area of $625 \mathrm{~m}^{2}$ [18] were made. In addition, observations of the ecotope (slope; exposition; altitude; general, nano and micro relief) were made in the 
place of the samples and their surroundings.

For the characteristic combination of the associations, the species with degrees of presence IV and V [24] were used, and for the subassociations and variants the differential combinations.

Weber et al. [25] was followed for the categorization and the name of syntaxa. Completed scientific names (genus, species and author) are observed in Tables and AcevedoRodriguez \& Strong [1], sometime ameded by Greuter \& Rankin Rodriguez [10, 11], Borhidi et al. [2] and Sanchez [20, 21]. Collected specimens are in Herbarium BSC.

\section{Results}

In this work the subsequent phytosociological arrangement was made:

Clase Clidemio - Cyatheetea arboreae Reyes clas. nov.

Holotypus: Andropogono-Coccocypseletalia lanceolati Reyes ord. nov.

Herbaceous and secondary scrub, constituted by the immediate and early secondary communities that develop in abandoned fields and slopes that are produced in the construction of the roads in areas of the submountain and mountain rainforests (sometimes known as cloud forests in the Antilles), it is generally rich in ferns.

The climate is tropical, with rainfall between 1200 and 3 $500 \mathrm{~mm}$. It was studied in rainforest ecotopes in Nipe Sagua Baracoa and Sierra Maestra, observed in the Central Mountain Range of the Dominican Republic and similar types of vegetation were described from the mountains of Puerto Rico.

Character species. Strongly associated: Cyathea arborea, Gleichenella pectinata, Sticherus bifidus, Lycopodiella cernua, Nephrolepis brownii, N. biserrata, Miconia umbellata, Clidemia hirta, Pitirogramma calomelanus, Rhytidophyllum exsertum, favorably associated: Myrsine coriacea, Desmodium triflorum, D. canum, D. axillare, Tibouchina longifolia, Spermacoce laevis, Andropogon virginicus, A. bicornis, Piper aduncum, Pluchea carolinensis, Miconia prasina, Phaius tankervilliae, Homolepis glutinosa, Coccocypselum lanceolatum and Mikania spp.

This class has two orders that distinguish the two mountain massif of Eastern Cuba:

1) Andropogono-Coccocypseletalia lanceolati (in Sierra Maestra),

2) Clidemio-Cyatheetalia arboreae (in metamorphic rocks of Sagua Baracoa).

In this work is only descripted the order corresponding to
Sagua Baracoa.

Clidemio-Cyatheetalia arboreae Reyes ord. nov.

Holotypus: Miconio prasinae-Cyatheion arboreae all. nov.

Secondary scrub- and grasslands, constitute by immediate and early secondary communities developed in abandoned fields and pasture lands, and in produced talus (roadbanks) as a result of road built in ecotopes of rainforest over metamorphic rocks, it is generally rich in ferns. Weather is warm, tropical, with rainfall levels for about 1200 to 3500 $\mathrm{mm}$.

Composition - characteristics species. Cyathea horrida, $C$. arborea, Sticherus bifidus, Lycopodiella cernua, Tibouchina longifolia, Pitirogramma calomelanus, Nephrolepis brownii, N. biserrata, Miconia prasina, Piper aduncum, P. arboreum, Clidemia hirta, C. umbellata, Urena lobata, Desmodium triflorum, D. canum, Spermacoce laevis, Elephantopus scaber, Andropogon virginicus, A. bicornis, Bidens pilosa, Gleichenella pectinata, Rhytidophyllum exsertum, Pluchea carolinensis and Blechnum occidentale.

Studied alliances:

1) Miconio prasinae-Cyatheion arboreae,

2) Tibouchino longifoliae-Sticherion bifidi.

In this work we only will study Miconio prasinaeCyatheion arboreae alliance.

Miconio prasinae-Cyatheion arboreae Reyes all. nov.

Holotypus: Clidemio-Cyatheetum arboreae ass. nov.

Secondary scrub- and grasslands, constitute by immediate and early secondary communities developed in abandoned fields and pasture lands, as in talus (roadbanks) as a result of road built in ecotopes of rainforest over metamorphic rocks, it is generally rich in ferns. Weather is warm, tropical, with rainfall levels for about 1200 to $3500 \mathrm{~mm}$.

Composition - characteristics species. Strongly associated: Cyathea horrida, favorably associated: Cyathea arborea, Blechnum occidentale, Nephrolepis brownii, Miconia prasina, Piper aduncum, P. arboreum, Clidemia hirta, Urena lobata, Desmodium triflorum, D. canum, Spermacoce laevis and Elephantopus scaber.

From five associations in these alliance we only will study three in this work.

Studied associations in this work:

1) Neurolaeno lobatae-Lantanetum camarae,

2) Ureno lobatae-Miconietum prasinae,

3) Cyatheetum horrido arboreae.

Neurolaeno lobatae-Lantanetum camarae Reyes ass. nov. Table 1, holotypus inv. 1 .

Table 1. Neurolaeno lobatae - Lantanetum camarae. Presen=presence.

\begin{tabular}{lll}
\hline N. order & $\mathbf{1}$ & $\mathbf{2}$ \\
\hline Altitude (mosl) & 450 & 460 \\
Inclination (degrees) & 60 & 20 \\
Exposition & $\mathrm{N}$ & $\mathrm{NW}$ \\
E $_{2}$ - Shrub layer (covers \%) & 10 &. \\
E $_{1}$ - Herbaceous layer (\%) & 90 & 100 \\
N. species & 41 & 35 \\
Characteristics & & \\
E $_{2,1}$ - Lantana camara L. & 1.1 & 2.2 \\
\hline
\end{tabular}




\begin{tabular}{llll}
\hline N. order & $\mathbf{1}$ & $\mathbf{2}$ & Presen \\
\hline Clidemia umbellata (Mill.) L. O. Wms. & 1.1 & +.2 & $2(+-1)$ \\
Calyptronoma occidentalis (Sw.) H. E. Moore & +.1 & +.1 & $2(+)$ \\
E1- Neurolaena lobata (L.) R. Br. ex Cass. & 3.2 & 3.2 & $2(3)$ \\
Cyathea arborea (L.) J. Sm. & 1.2 & $\mathrm{r} .1$ & $2(\mathrm{r}-1)$ \\
Chromolaena odorata (L.) R. Br. & 1.1 & +.1 & $2(+-1)$ \\
Tibouchina longifolia (Vahl) Baillon & 1.1 & +.1 & $2(+-1)$ \\
Urena lobata L. & 1.1 & +.1 & $2(+-1)$ \\
Casearia sylvestris Sw. var. sylvestris & +.1 & +.1 & $2(+)$ \\
Clidemia hirta (L.) D. Don & 1.1 & +.1 & $2(+-1)$ \\
Miconia prasina (Sw.) DC. & $\mathrm{r} .1$ & +.1 & $2(\mathrm{r}-+)$ \\
Pluchea carolinensis (Jacq.) G. Don in Sweet. & +.1 & +.1 & $2(+)$ \\
Psidium guajava L. & +.1 & $\mathrm{r} .1$ & $2(\mathrm{r}-+)$ \\
Elephantopus scaber L. & +.1 & +.1 & $2(+)$ \\
Coccocypselum herbaceum Aubl. & $\mathrm{r} .1$ & 1.2 & $2(\mathrm{r}-1)$ \\
Phaius tankervilliae (Banks) Blume & $\mathrm{r} .1$ & $\mathrm{r} .1$ & $2(\mathrm{r})$ \\
Polygala leptocaulis T. \& G. & 1.1 & +.1 & $2(+-1)$ \\
Stachytarpheta cayennensis (L. C. Rich.) Vahl & +.1 & 2.2 & $2(+-2)$ \\
Spermacoce laevis Lam. & 1.2 & 3.2 & $2(1-3)$ \\
Rhynchospora colorata (L.) H. Pfeiff. & $\mathrm{r} .2$ & 2.2 & $2(\mathrm{r}-2)$ \\
Sida rhombifolia L. & +.1 & 3.2 & $2(+-3)$ \\
Pityrogramma calomelanus (L.) Link & $\mathrm{r} .2$ & +.2 & $2(\mathrm{r}-+)$ \\
Nephrolepis biserrata (Sw.) Schott & +.2 & +.2 & $2(+)$ \\
Lygodium volubile Sw. & $\mathrm{r} .1$ & $\mathrm{r} .1$ & $2(\mathrm{r})$ \\
Odontosoria aculeata (L.) J. Sm. & +.1 & +.1 & $2(+)$ \\
\hline
\end{tabular}

In addition. Inv. 1. Zanthoxylum martinicense (Lam.) DC. +.1, Guarea guidonia (L.) Sleumer +.1, Solanum nigrum L. +.1, Rhytidophyllum exsertum Griseb. +.1 , Desmodium canum (J. F. Gmel.) Schinz \& Thell. 1.1, D. triflorum (L.) P. DC. +.1 , Miconia sp. r.1, Andropogon bicornis L. +.2 , Scleria secans (L.) Britt. +.2 , Lycopodiella cernua (L.) Pic. Serm. +.2 , Ludwigia octovalvis (Jacq.) Raven r.1, Cupania americana L. +.1 , Alchornea latifolia Sw. +.1, Machaerina cubensis (Kuk.) T. Koyama r.2, Trema micranthum (L.) Blume r.1, Vernonia sp. +.1 ; Inv. 2. Guettarda sp. +.1 , Triunfetta semitriloba Jacq. +.1 , Citharexylum fruticosum L. r.1, Solanum torvum Sw. r.1, Piper peltata (L.) Miq. r.1, Panicum sp. 1.2, Emilia sonchifolia (L.) DC. r.1, Andropogon virginicus L. r.2, Bactris cubensis Burret (+.1), Adiantum pyramidale (L.) Wild. +.2.

In this phytocoenose is observed a pioneering group of heliophilous (sun-loving) species, synantropic much of them, that are absent in much of the advanced successional stages, between they: Lantana camara, Neurolaena lobata, Chromolaena odorata, Polygala leptocaulis, Stachytarpheta cayennensis, Rhynchospora colorata, Solanum nigrum, S. torvum, Andropogon bicornis, A. virginicus, Ludwigia octovalvis, Emilia sonchifolia, Sida rhombifolia, and other species (Table 1). Was study 12.02.2004 (N20 17.2', W74 $\left.43^{\prime}\right)$.

Ureno lobatae-Miconietum prasinae Reyes ass. nov. Table 2, holotypus inv. 1.

This early community is found in very relatively small slopes to the areas (22 degrees) and in the superior part of the south slope of the hill, soils are ferralitics red, sometime leached soils with clay and loam, generally lacking gravels in the profile, internal drainage is good.

This pasture land has a dense shrublike-herbaceous layer with $100 \%$ cover, in the more developed areas there are some isolated specimens of Byrsonima tetraphylla and Eugenia pinetorum that reach eight meters.

More abundant specie is Miconia prasina, sometime abundant are Nephrolepis brownii, Elephantopus scaber and Spermacoce laevis, the rest with less cover (Table 2). Was characterized 13-15.02.2004 (N20¹7.2', W74 $\left.{ }^{\circ} 43.4^{\prime}\right)$.

Table 2. Ureno lobatae-Miconietum prasinae.

\begin{tabular}{|c|c|c|c|c|c|c|}
\hline N. order & 1 & 2 & 3 & 4 & 5 & Presen \\
\hline Altitude (mosl) & 580 & 590 & 540 & 540 & 560 & \\
\hline Inclination (degrees) & 20 & 20 & 12 & 20 & 45 & \\
\hline Exposition & WSW & WSW & NW & $\mathrm{W}$ & SSW & \\
\hline $\mathrm{E}_{3}$ - Canopy layer (covers \%) & . & . & 20 & . & 30 & \\
\hline $\mathrm{E}_{2}$ - Shrub layer (\%) & 80 & 100 & 85 & 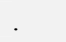 & 90 & \\
\hline$E_{1}$ - Herbaceous layer (\%) & 85 & 20 & 100 & 100 & 95 & \\
\hline N. species & 21 & 20 & 24 & 28 & 36 & 25.8 \\
\hline \multicolumn{7}{|l|}{ Characteristics } \\
\hline $\mathrm{E}_{2,1}-$ Miconia prasina $(\mathrm{Sw}.) \mathrm{DC}$. & 4.4 & 5.5 & 5.5 & 4.3 & 5.5 & $5(4-5)$ \\
\hline $\mathrm{E}_{1}$ - Urena lobata $\mathrm{L}$. & 1.1 & +.1 & 1.1 & 1.1 & +.1 & $5(+-1)$ \\
\hline Clidemia hirta (L.) D. Don & 1.1 & r.1 & r.1 & 1.1 & +.1 & $5(\mathrm{r}-1)$ \\
\hline Spermacoce laevis Lam. & r.1 & r.1 & 1.1 & 3.2 & +.1 & $5(\mathrm{r}-3)$ \\
\hline Elephantopus scaber $\mathrm{L}$. & r.1 & +.1 & 1.1 & 3.2 & 1.1 & $5(\mathrm{r}-3)$ \\
\hline Nephrolepis brownii (Desv.) Hovenk. \& Miyam. & 4.3 & +.2 & 4.4 & +.2 & +.2 & $5(+-4)$ \\
\hline $\mathrm{E}_{2,1}-$ Cupania americana $\mathrm{L}$. & r.1 & r.1 & r.1 & & 2.1 & $4(r-2)$ \\
\hline $\mathrm{E}_{1}$-Desmodium axillare (Sw.) P. DC. & 1.2 & . & 1.2 & +.1 & +.1 & $4(+-1)$ \\
\hline Axonopus compressus (Sw.) Beauv. & +.2 & 1.2 & 1.2 & r.2 & & $4(\mathrm{r}-1)$ \\
\hline
\end{tabular}




\begin{tabular}{|c|c|c|c|c|c|c|}
\hline N. order & 1 & 2 & 3 & 4 & 5 & Presen \\
\hline $\begin{array}{l}\text { L- Mikania micrantha Kunth } \\
\text { Accompaniers }\end{array}$ & +.1 & r.1 & r.1 & r.1 & . & $4(\mathrm{r}-+)$ \\
\hline $\mathrm{E}_{2,1}$ - Psydium guajava $\mathrm{L}$. & r.1 & . & . & +.1 & 1.1 & $3(\mathrm{r}-1)$ \\
\hline $\mathrm{E}_{1}$ - Guarea guidonia (L.) Sleumer & r.1 & . & r.1 & . & +.1 & $3(\mathrm{r}-+)$ \\
\hline Triunfetta semitriloba Jacq. & r. 1 & . & +.1 & +.1 & . & $3(\mathrm{r}-+)$ \\
\hline Tibouchina longifolia (Vahl) Baillon & . & r.1 & . & +.1 & r.1 & $3(\mathrm{r}-+)$ \\
\hline Stachytarpheta cayennensis (L. C. Rich.) Vahl & r.1 & r.1 & . & 1.1 & . & $3(\mathrm{r}-1)$ \\
\hline Scleria secans (L.) Britt. & 1.2 & +.2 & 2.2 & 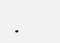 & . & $3(+-2)$ \\
\hline Lycopodiella cernua (L.) Pic. Serm. & 1.2 & . & . & 1.1 & +.1 & $3(+-1)$ \\
\hline Desmodium triflorum (L.) P. DC. & . & r.2 & . & +.2 & +.2 & $3(\mathrm{r}-+)$ \\
\hline Oplismenus setarius (Lam.) R. \& S. & . & +.2 & 1.2 & & 1.2 & $3(+-1)$ \\
\hline Scleria lithosperma (L.) Sw. & . & $\mathrm{r} .2$ & . & 2.2 & 3.2 & $3(r-3)$ \\
\hline Spathoglottis plicata Blume & . & r.2 & r.1 & . & +.1 & $3(\mathrm{r}-+)$ \\
\hline Blechnum occidentale $\mathrm{L}$. & . & $\mathrm{r} .2$ & 2.2 & & 4.3 & $3(\mathrm{r}-4)$ \\
\hline $\mathrm{E}_{2,1}$ - Piper aduncum $\mathrm{L}$. & . & . & . & 2.1 & r.1 & $2(r-2)$ \\
\hline $\mathrm{E}_{1}$ - Piper umbellatum $\mathrm{L}$. & . & r.1 & . & r.1 & 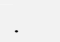 & $2(\mathrm{r})$ \\
\hline Andropogon bicornis $\mathrm{L}$. & +.2 & . & . & 2.2 & ${ }^{\circ}$ & $2(+-2)$ \\
\hline Hyptis verticillata Jacq. & . & . & . & r.1 & r.1 & $2(\mathrm{r})$ \\
\hline Desmodium canum (J. F. Gmel.) Schinz \& Thell. & . & . & . & 1.2 & +.2 & $2(+-1)$ \\
\hline Cyathea horrida $\mathrm{L}$. & $\mathrm{r} .2$ & r.2 & . & . & . & $2(\mathrm{r})$ \\
\hline L- Turbina corymbosa (L.) Hall. & r.1 & r.1 & & & & $2(\mathrm{r})$ \\
\hline
\end{tabular}

In addition. Inv. 1. Coccocypselum herbaceum Aubl. +.2, Passiflora suberosa L. r.1; Inv. 2. Gleichenella pectinata (Willd.) Ching 2.2; Inv. 3. Bactris cubensis Burret r.1, Schefflera morototoni (Aubl.) Mag., Stey. \& Frodin r.1, Calyptronoma occidentalis (Sw.) H. E. Moore +.1, Buchenavia tetraphylla (Aubl.) R. A. Howard (+.1), Telypteris reticulata (L.) Proctor r.2, Guazuma ulmifolia Lam. r.1, Zyzygium jambos (L.) Alston r.1, Pisonia aculeata L. r.1; Inv. 4. Chromolaena odorata (L.) King \& Robins. 1.1, Vernonia cinerea (L.) Less. r.1, Sida rhombifolia L. r.1, Canavalia sp. r.1, Clidemia umbellata (Mill.) L. O. Wms. r.1, Mimosa pudica L. +.1, Spiranthes lanceolata (Aubl.) León r.1; Inv. 5. Sapium jamaicense Sw. +.1, Chrysophyllum oliviforme L. 1.1, Cecropia peltata L. +.1, Cyathea arborea (L.) J. Sm. +.1, Clusia rosea Jacq. 1.2, Spondias mombin L. +.1, Alchornea latifolia Sw. r.1, Rhytidophyllum exsertum Griseb. 1.1, Eugenia pinetorum Urb. +.1 , Phaius tankervilliae (Banks) Blume r.1, Macrotelypteris torresiana (Gaudich.) Ching r.2, Adiantum sp. +.2 , Guzmania monostachia (L.) Rusby ex Mez +.2, Solanum antillarum O. E. Schulz. r.1, Vitis tiliifolia H.\& B. 1.1, Lygodium volubile Sw. r.1.

Cyatheetum horrido arboreae Reyes ass. nov. Table 3, holotypus inv. 1.

This phytocoenose represent an early community formed for the abandonment of a pasture land and a crop field respectively in northern expositions. Nowadays constitute a Homeostasis I and beginning of Fiera II also, in which mainly Cyathea arborea constitute a dominant layer between 7 and $10 \mathrm{~m}$ high.

It is developed over a yellow and leached ferralitic soil, loamed and with gravels, in which is observed a dense rootlets (rhizoids) of the tree fern before mentioned in the first 4 or $5 \mathrm{~cm}$ of the profile, at $10 \mathrm{~cm}$ deep this rhizoids are not found. The humus layers are absent, principally fronds of dominant fern are observed; is considered that moreover of a fast decomposition, because of the big slope the formed humus will be drag for the intensity of rainfalls.

In the inventory 2 is observed that trees break the Cyathea arborea layer and interact between them, beginning the stage knowing as Fiera II. The species here present are: Ficus membranacea, Cupania glabra, C. americana, Cecropia peltata, Cordia sulcata, Guarea guidonia, Casearia sylvestris subsp. sylvestris, Zanthoxylum martinicense and Spondias mombin.

The shrub layer is very variable in its cover the more prominent specie is Miconia prasina and in the second inventor also Calyptronoma occidentalis, and the rest have less cover. The herbaceous layer is the more floral diverse, the majority of species are scarcely (Table 3). In the 15.02.2004 (N20¹7', W7443.4') was study.

Table 3. Cyatheetum horrido arboreae.

\begin{tabular}{|c|c|c|c|}
\hline N. order & 1 & 2 & Presen \\
\hline Altitude (mosl) & 480 & 300 & \\
\hline Inclination (degrees) & 40 & 50 & \\
\hline Exposition & NNW & NNE & \\
\hline $\mathrm{E}_{3}$ - Canopy layer $(\%)$ & 60 & 70 & \\
\hline$E_{2}-$ Shrub layer $(\%)$ & 10 & 60 & \\
\hline$E_{1}$ - Herbaceous layer $(\%)$ & 80 & 50 & \\
\hline N. species & 26 & 39 & 32.5 \\
\hline $\mathrm{E}_{3,2^{-}}$Cyathea arborea (L.) J. Sm. & 4.4 & 3.2 & $2(3-4)$ \\
\hline Cordia sulcata DC. & +.1 & +.1 & $2(+)$ \\
\hline $\mathrm{E}_{3,2,1}-$ Cupania americana $\mathrm{L}$. & +.1 & 1.1 & $2(+-1)$ \\
\hline $\mathrm{E}_{3,1^{-}}$Casearia sylvestris $\mathrm{Sw}$. subsp. sylvestris & +.1 & +.1 & $2(+)$ \\
\hline $\mathrm{E}_{2,1}-$ Miconia prasina (Sw.) DC. & 3.2 & 3.1 & $2(3)$ \\
\hline Cyathea horrida (L.) Sm. & 1.1 & 1.1 & $2(1)$ \\
\hline Calyptronoma occidentalis (Sw.) H. E. Moore & r. 1 & 2.1 & $2(r-2)$ \\
\hline Rhytidophyllum exsertum Urb. & +.1 & +.1 & $2(+)$ \\
\hline
\end{tabular}




\begin{tabular}{llll}
\hline N. order & $\mathbf{1}$ & $\mathbf{2}$ & Presen \\
\hline $\mathrm{E}_{2}$ - Chrysophyllum argenteum Jacq. & +.1 & 1.1 & $2(+-1)$ \\
$\mathrm{E}_{1}$ - Dendropanax arboreus Dene. \& Planch. & $\mathrm{r} .1$ & +.1 & $2(\mathrm{r}-+)$ \\
Phaius tankervilliae (Banks) Blume & +.1 & +.1 & $2(+)$ \\
Piper arboreum Aubl. & $\mathrm{r} .1$ & +.1 & $2(\mathrm{r}-+)$ \\
Clidemia hirta (L.) D. Don & $\mathrm{r} .1$ & +.1 & $2(\mathrm{r}-+)$ \\
Danaea elliptica Sm. & $\mathrm{r} .1$ & +.1 & $2(\mathrm{r}-+)$ \\
Ep- Columnea cubensis (Urb.) Britt. & +.1 & +.1 & $2(+)$ \\
\hline
\end{tabular}

In addition. Inv. 1. Panicum sp. 3.2, Scleria melaleuca Reichb. +.2, Coccocypselum herbaceum Aubl. r.1, Neurolaena lobata (L.) R. Br. r.1, Miconia sp. r.1, Hemidictyum marginatum (L.) C. Presl r.1, Diplazium unilobum (Poir.) Hieron. r.2, Adiantum pyramidale (L.) Wild. +.2, Lygodium volubile Sw. +.1, Platygyna sp. +.1 , Pentalinon luteum (L.) Hansen \& Wunderlin r.1; Inv. 2. Ficus membranacea C. Wr. +.1, Cupania glabra Sw. 2.1, Guarea guidonia (L.) Sleumer +.1, Cecropia peltata L.+.1, Zanthoxylum martinicense (Lam.) DC. +.1, Spondias mombin L. +.1, Piper aduncum L. +.1, Psychotria grandis Sw. +.1, Pavonia fruticosa (Mill.) Fawcett \& Rendle +.1, Desmodium canum (J. F. Gmel.) Schinz \& Thell. r.1, D. triflorum (L.) P. DC. 2.1, Costus cylindricus Jacq. +.1, Conostegia xalapensis D. Don +.1, Elephantopus scaber L. r.1, Tibouchina longifolia (Vahl) Baillon +.1 , Begonia wrightiana A. DC. +.1, Schefflera morototoni (Aubl.) Mag., Stey. \& Frodin +.1, Commelina sp. r.1, Tournefortia bicolor Sw. +.1, Gesneria sp. +.1, Rhynchospora colorata (L.) H. Pfeiff. r.2, Urena lobata L. r.1, Passiflora sexflora A. Juss. +.1, Psychotria greeneana Urb. r.1.

\section{Discussion}

In the syntaxa evolution of submountain rainforest over metamorphic rocks [19], when a secondary stage (field or pasture land) is cut, burn and late abandoned it will conform a immediate secondary community like Neurolaeno lobatae - Lantanetum camarae association.

Result very interesting to observe how during these first stages of the serie the majority of species are of herbaceous type, frequently with ferns dominance. However with the succession advanced process (immediat, early and late communities) obviously the structural complexity grow (Table 3).

Its consolidate the concept that in this first stages of the serie almost the totality of species are heliophilous mainly with a type of "r" selection $[9,19]$ and only exceptionally arboreal elements of mature rainforest are found [18].

It is confirmed that in the studied area, due the great levels of precipitations and its relatively uniformity, in the Homeostasis I a differentiation of associations is produced as a function of exposure. The elements of the north exposure develop a dominant community of Cyathea arborea, while those that evolutioned in south exposure Miconia prasina is the predominant. This is also a coincidence with the importance of this exposition for the cultivation of arum (Xanthosoma sagittifolium Schott.); R. Ruiz (com. pers.) said that arum cultivate in north exposure putrefy, while in south exposure has a normal develop.

It is to important to emphasize how in the developed communities with tree ferns predominance its rhizoids conform a dense layer that protect the soil against the erosion, which is a coincidence that soft roots predominate in this first stages [5, 6]. This communities are very similar to the humid forest of México where Cyatheaceae are very distinguished elements [17].

It is outstanding that in the Fiera II beginning for be located in the surrounded of a mature forest the seeds rain function have a great efficiency to arboreal species enter. Is also considered that in this stages the majority of biomass found as stems and leaves, frequently is not woody [12].

\section{Conclusions}

When a secondary succession developed, in the first stages, communities are represented mainly by herbaceous pioneers heliophilous with a type " $\mathrm{r}$ " selection that are also generalist species. We also observed that in the Homeostasis I, with a small arboreal layer, the exposition defines the dominant species in the canopy in these places with leached ferralitic soil originating from metamorphic rocks with 2,500 to $3,000 \mathrm{~mm}$ annual rainfall. It is also considered that canopy species entry is produced in the surroundings of the forest as a result of seeds rain.

\section{References}

[1] Acevedo-Rodriguez, P. \& M. T. Strong. 2012. Catalogue of Seed Plants of the West Indies. Smithsonian Contributions to Botany $98.1192 \mathrm{p}$.

[2] Borhidi, A., M. Fernández-Zequeira \& R. Oviedo Prieto. 2017. Rubiáceas de Cuba. Budapest. Akademiai Kiadó. 494 p.

[3] Braun Blanquet, J. 1951. Pflanzensoziologie; Grundzüge der Vegetationskunde. 2 Aufl. Wien.

[4] Caluff, M. G. 2015. Pérdida de biodiversidad pteridológica en diferentes formas de uso de la pluvisilva de baja altitud sobre complejo metamórfico. En Pluvisilvas cubanas: tesoro de biodiversidad. p. 149-156. La Habana.

[5] Carvalheiro, K. \& D. C. Nepstat 1996. Deep soil heterogeneity and fine root distribution in forests and pastures of eastern Amazonia. Plant and Soil 182: 279-285.

[6] Cavelier, J., J. Estevez \& B. Arjona. 1996. Fine root biomass in three successional stages of an Andean cloud forest in Colombia. Biotrópica 28: 728-736.

[7] Colectivo de Autores. 2013. Léxico estratigráfico de Cuba. Instituto de Geología y Paleontología (IGP) y Servicio Geológico de Cuba. Coordinador General Jorge de Huelbes Alonso.

[8] Figueredo, L. M., F. Acosta, O. J. Reyes \& E. Fornaris. 2012. Caracterización de la vegetación de las Terrazas Costeras de la Reserva de la Biosfera Baconao, Santiago de Cuba, Cuba. Brenesia 78: 25-33. 
[9] Gliessman, S. R. 2002. Agroecología: Procesos ecológicos en agricultura sostenible. CATIE, Turrialba.

[10] Greuter, W. \& R. Rankin Rodríguez. 2016. The Spermatophyta of Cuba. A Preliminary Checklist. Part II: Checklist. Botanischer Garten \& Botanisches Museum Berlin-Dahlem \& Jardín Botánico Nacional, Universidad de La Habana. 398 p.

[11] Greuter, W. \& R. Rankin Rodríguez. 2017. Vascular plants of Cuba. A preliminary checklist. Second, updated Edition of The Spermatophyte of Cuba, with Pteridophyte added. Botanischer Garten - Botanisches Museum Berlin-Dahlem \& Jardín Botánico Nacional, Universidad de la Habana. 444 p.

[12] Guariguata, M. R. \& R. Ostertag. 2002. Sucesión secundaria. En M. R. Guariguata \& G. H. Kattan (eds). Ecología de bosques neotropicales. Editorial Tecnológica, Cartago, Costa Rica. 591-623 p.

[13] Guevara, V., Y. Rodriguez \& A. Roque (Redactores Temáticos). 2019. Precipitación media hiperanual 1961-2000. En: Atlas Nacional de Cuba LX Aniversario. La Habana.

[14] Hernández A., J. M. Pérez Jiménez, D. Bosh \& N. Castro Speck. 2015. Clasificación de los Suelos de Cuba 2015. Instituto Suelos e Instituto Nacional de Ciencias Agrícolas. La Habana.

[15] Pérez, E., N. Enríquez, N. Martínez González, L. Alfonso Ferrá \& R. Rivero Vega. 2004. Reforestación sucesional en la Sierra de Cubitas, Estudio de Caso: Boca de Domínguez. Camaguey, Cuba. Biodiversidad de Cuba Oriental, Editorial Academia 7: 32-45.

[16] Pérez Carreras, E. \& N. Enriquez Salgueiro. 2004. La sucesión vegetal como proceso natural para el mantenimiento de la diversidad biológica en los Matorrales xeromorfos espinosos de la llanura serpentínica de Maraguán, Camaguey. Biodiversidad de Cuba Oriental, Editorial Academia 7: 79-92.
[17] Pérez-Paredes, M. G., A. Sánchez-González \& J. D. TejeroDíez. 2014. Estructura poblacional y características del hábitat de dos especies de Cyatheaceae del estado de Hidalgo, México. Botanical Science 92 (2). versión On-line ISSN 2007-4476 versión impresa ISSN 2007-4298.

[18] Reyes, O. J. 2005. Estudio sinecológico de las pluvisilvas submontanas sobre rocas del complejo metamórfico. Foresta Veracruzana 7 (2): 15-22.

[19] Reyes, O. J. \& F. Acosta Cantillo. 2007. La sucesión vegetal en la Pluvisilva submontana sobre rocas metamórficas en las Cuchillas y Mesas de Baracoa - Imías. Memorias II Simposio Internacional sobre Restauración Ecológica. Texto 56. ISBN 978-959-250-322-9. $11 \mathrm{p}$.

[20] Sánchez, C. 2017. Lista de los helechos y licófitos de Cuba. Brittonia, DOI 10.1007/s12228 017-9485-1. ISSN: 0007196X (print) ISSN: 1938-436X (electronic, published online 23 June 2017). 24 p.

[21] Sánchez, C. 2021. Inventario de los licófitos y helechos de Cuba: sinonimia, distribución y estado de conservación. Revista del Jardín Botánico Nacional 42: 1-53.

[22] Sánchez-Ruiz, A. 2001. Efectos de los cambios de uso del suelo sobre la fauna de arañas (Arachnida: Araneae) en el macizo Sagua Baracoa, Cuba. AvaCient. 32: 3-12.

[23] Sanchez-Ruiz, A. 2015. Principales daños sobre las comunidades de arañas (Arachnida: Araneae) provocadas por la deforestación de los bosques en los macizos montañosos del oriente de Cuba. Pluvisilvas cubanas: tesoro de biodiversidad. p. 195-198. La Habana.

[24] Scamoni, A. 1960. Waldgesellschaften und Waldstandorte. Akademie-Verlag. Berlin. 326 p.

[25] Weber, H. E., J. Moravec, \& J. P. Theurillat. 2000. Internacional Code of Phytosociological Nomenclature. 3rd Edition. Journal of Vegetation Science 11: 739-768. 